\title{
Three-dimensional CT Colonography
}

\author{
小倉敏裕・小泉浩－1) ·高津一朗
}

\section{癌研究会附属病院放射線部}

1 ) 癌研究会附属病院内科

\section{緒 镸}

当院ではCTデータを利用した上部，下部消化器癌

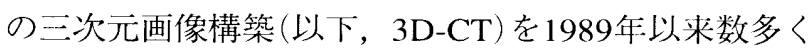

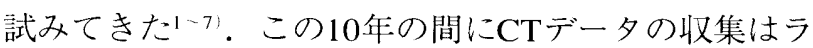
ピッドシーケンススキャン，へリカルスキャン，マル チスライスヘリカルスキャンと変遷を重ね，同時に三 次元構築プログラムも急速に進歩した。現在，大腸癌 と診断された症例で術前の病期診断のため，マルチス ライスCTによって肝臓を含めた全腹スキャンを行っ
ている。そのボリュームデー夕を利用し3D-CTcolonographyを作成している8,9'. CAD (computeraided diagnosis) とはコンピュータを用いて放射線画像 の解析および定量化を自動的に行い，その分析結果を 参考にして読影医師が自分の判断も加えて最終的な診 断を下すことである(1). 3D-CT-colonographyの場合, 大腸管腔を自動的にナビゲートしながら視点を進め同 時に診断支援，すなわち放射線画像の解析および定量 を自動的に行うというところまで進んでいないのが現

\section{Three-dimensional CT Colonography TOSHIHIRO OGURA, KOUICHI KOIZUMI," and KAZUAKI TAKATSU \\ Department of Radiology, Cancer Institute Hospital \\ 1 ) Department of Internal Medicine, Cancer Institute Hospital \\ Received Oct. 26, 1999; Revision accepted Jan. 11, 2000; Code No. 251}

\section{4ted Summary}

We have conducted research on three-dimensional (3D)-computed tomography $(\mathrm{CT})$-colonography with single and multi-slice helical CT scanning, a recent topic of special interest. CT provides multiple ways to detect colorectal neoplasia including standard axial CT, multiplanar reconstruction (MPR), and 3D-CTcolonography. Furthermore, 3D-CT-colonography offers several methods of visualization using volumetric CT data depending on the threshold setting of CT values. The flythrough system of virtual colonoscopy is worthy of note for computer-aided diagnosis (CAD). Virtual colonoscopy provides real-time endoscopic viewing that simulates fiber-optic endoscopy, by simply pointing at a location in the MPR view. Virtual colonoscopy makes it possible to advance confidently into the digestive tract, except for highly tortuous colons, to turn rapidly at the end of the digestive tract, and to return back along the tract. This method could potentially reduce non-visualized areas between haustra of the colon, but virtual colonoscopy sometimes has difficulty distinguishing polyps from feces. This problem is largely avoided by applying synthesized 3D and MPR images (3D-MPR-CT), which can provide information on the intraluminal orientation of focal abnormalities. Therefore, with progress in CAD, we believe that, combined with the flythrough system and 3D-MPR$\mathrm{CT}$, virtual colonoscopy might be applied in the future as first-line examinations in screening for colorectal neoplasia.

\section{Key words: Computed tomography $(X-C T)$, Helical CT, Three-dimensional imaging, Virtual endoscopy}


状である。しかし，コンピュータ支援による画像診断 という観点から見直してみるとvirtual endoscopyをは じめCTデータを用いた三次元構築画像はCADの一つ として位置付けることができよう。ここでは，通常の 大腸のCT検査に診断情報を付加するコンピュータ支 援診断としての3D-CT-colonographyについて述べる.

\section{1. 方 法}

\section{1-1 使用機器}

CT装置は複数検出器列CT, LightSpeed QX/i (GE横 河メディカルシステム)を使用.

診断支援ワークステーションはAdvantage Workstation/ 64bit Ultra SPARC (GE横河メディカルシステム) を使用した。

\section{1-2 スキャン条件}

撮影条件は管電圧 $120 \mathrm{kV}$ ，管電流 $180 \mathrm{~mA}, 1$ 回転当 たりの照射時間は0.8secである。検出器は体軸方向に $1.25 \mathrm{~mm}$ 幅のディテクタアレイが16列ある.ここでは 4 列の検出器を $5 \mathrm{~mm}$ 幅の一つの出力チャンネルとして 使用した。すなわち 1 スライス当たりの幅は $5 \mathrm{~mm}$ と なる．管球 1 回転当たりの検出範囲は $1.25 \mathrm{~mm} \times 16$ 列 $=20 \mathrm{~mm}$ である．管球 1 回転当たりのテーブル移動距 離を一つの出力チャンネルが受け持つ素子の構成単位 で割った值helical pitch $\left.{ }^{11}\right)$ は 6 を使用した。すなわち 寝台移動速度は $30 \mathrm{~mm} /$ 回転となる．スキャン時間は腹 部全体を $45 \mathrm{~cm}$ とすると, $450 \mathrm{~mm}$ (腹部全長) $\div 30 \mathrm{~mm} /$ 回 転 (寝台移動距離/管球 1 回転) $\times 0.8 \mathrm{sec}$ (管球 1 回転) $=12 \mathrm{sec}$ となる. 再構成画像間隔は $1 \mathrm{~mm}$ とし $450 \mathrm{~mm}$ 当 たり450枚の二次元横断像を作成した.

\section{1-3 撮影方法}

当院では医師がルーチンに経肛門的に腹満を訴える

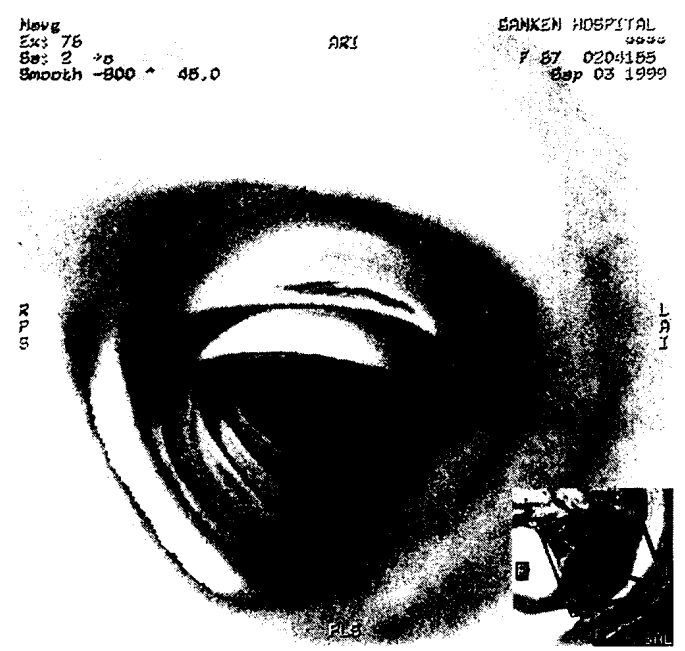

Fig. 1 Virtual endoscopy image of descending colon inflated with air.
まで送気するため, ボリュームデータをそのまま3DCTに利用できた。なお，転移検索などのための造影剤 としてスキャン開始70秒前に非イオン性造影剤100ml を $1.5 \mathrm{ml} / \mathrm{sec} て ゙$ 静注した1ー7). 3D-CTは二次元横断像の 画像データをAdvantage Workstationに転送し, ボリュ ームレンダリングおよびサーフェイスレンダリング法 によって作成した．前処置は基本的にはポリエチレン グリコール $(\mathrm{PEG})$ 溶液による経口腸管洗浄法である が，直腸を目的とした場合特に処置は行わない．蠕動 を抑制するために鎮㾏剤の筋注を行う場合もある.

\section{2. 結 果}

消化管の3D-CT は体内に存在する空気と臓器実質と の間に生ずる大きなCT值の開きを利用する．消化管 3D-CT画像には, CT值の閾値と不透明度 (opacity)の 設定方法により，virtual endoscopy法(以下，VE)，air image法, 3D-CT二重造影法 (double-contrast CT colonography: 以下, DCCT), multiplanar reconstruction (以下, $M^{2} R^{12)}$ ) と3D-CT画像の合成表示を行った もの(以下, 3D-MPR-CT) 等の方法がある.

VEはいわゆる仮想内視鏡とも呼ばれ，管腔内腔の 形状把握に適応できる. Fig.1に示す下行結腸のVEの ように, 空気部分以外のCT値を抽出し, 空気部分の CT 值の範囲は完全に透明 (opacity 0\%) とする. 多く の胃や大腸の内視鏡画像との比較により，-700以上の CT值の抽出が最も粘膜面表示に近いことが判明して いる.内視鏡画像近似のVE画像を作成するときは, 近位の物体が大きく，遠位の物体が小さく表示される 透視投影法表示を行う。また，視野角度は $15^{\circ} \sim 60^{\circ}$ の 範囲で選択できる。VEのコンピュータ支援システム として最も際立つのがCT axial像, coronal像, sagittal 像において指定した位置の内視鏡画像がリアルタイム に観察できることである，通常axial像において，管腔 内の隆起，陷凹など管腔辺縁の形状異常を疑った場合 その病変近傍にカーソルを置くことにより瞬時に管腔 内壁の様子か確認できる．Fig.2a〜dに回盲部の潰瘍限 局型大腸癌のaxial像, coronal像, sagittal像およびそ の指定位置におけるVEを示す。axial像，coronal像， sagittal像の画像上で指定したメ印が視点を示しメ印か ら伸びる棒が視野方向を示す。ただし，三次元空間に おける視野であるので，正確な視点，視野方向を得る にはaxial像のみでなく, coronal像, sagittal像でも指 定する必要がある．本症例は回盲部に狭窄を伴った症 例で，Fig.2dのVEは内視鏡では越えられない狭窄をく ぐり抜け，狭窄部を観察した画像で，内視鏡における 観察では得られない像である．また，同一視点におい て $180^{\circ}$ 視野を反転させて観察したVEも瞬時に表示可 能である。Fig.2eは横行結腸を口側から肛門側に向か 


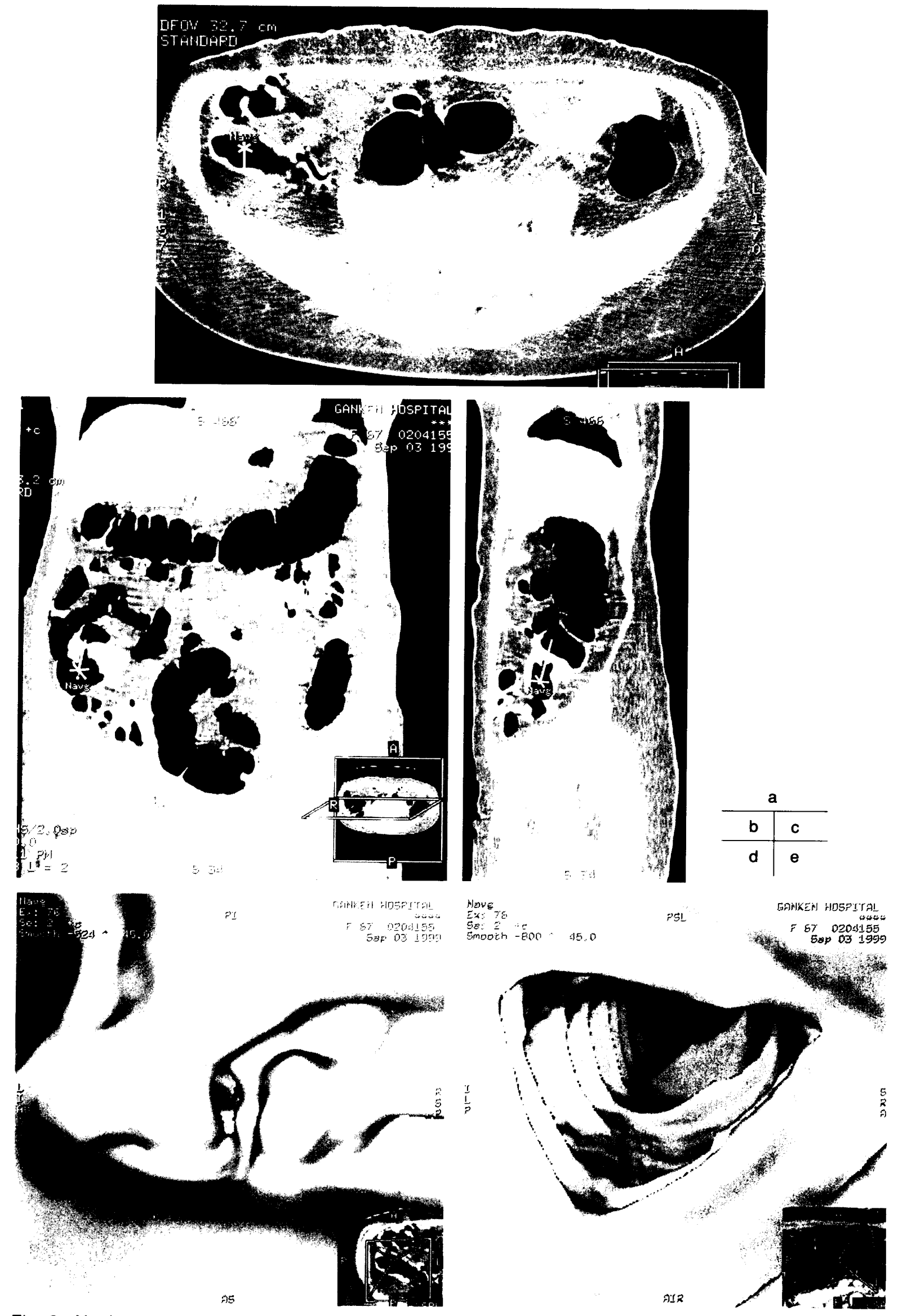

Fig. 2 Navigator program for colonic virtual endoscopy. We could obtain the various angles of virtual endoscopy images on a real-time basis; view angles were decided on the basis of the MPR images (a-c). Virtual endoscopy was able to pass through a narrowed lumen (d), something the videoendoscope was unable to do. This image shows carcinoma from the oral side. A virtual endoscopy image in the transverse colon obtained by reversal (e). 
つて観察した画像である.

Fig.3は大腸全体をair image法で表示したものである. 空気の部分の-700以下のCT值を抽出し，粘膜，臓器部 分のopacityを $0 \%$ とし管腔内の空気像を表示した。

管腔粘膜のCT值と空気のCT值には大きな開きがあ り，粘膜と空気の中間のCT值が存在する。DCCTは中 間のCT值(-700周辺) を抽出しray sumで半透明にて表 示した，X線二重造影法に近似した画像を構築する力

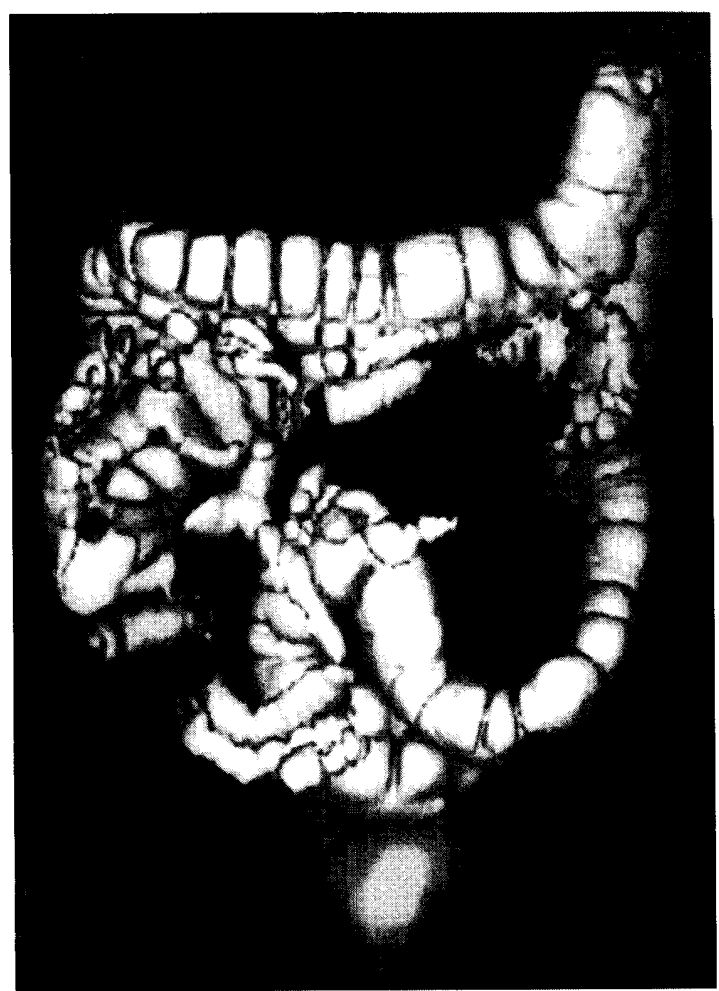

Fig. 3 An image visualized by the air image method looks like a single-contrast barium enema image.

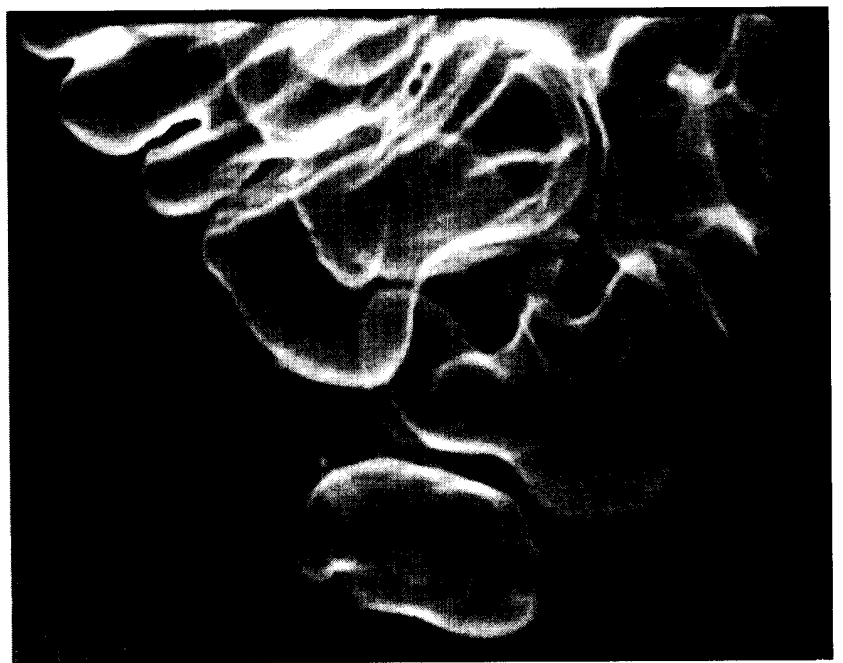

Fig. 4 This picture obtained by the double-contrast CT (DCCT) method is similar to that of a double-contrast barium enema image.
法である.Fig.4は回盲部のDCCTであるが，Fig.5の注 腸と比較すると解像力の点で若干劣るが，病変部およ び虫垂も描出され十分臨床に使用できる。この画像の メリットは，バリウムを使用することなくさまざまな 方向からの注腸近似像が得られることである。通常, X線撮影の場合直腸は 4 5 方向の撮影を行うが，本法 では 1 回のスキャンで済ませることができる。

ボリュームデータを用いて任意の方向の二次元断面

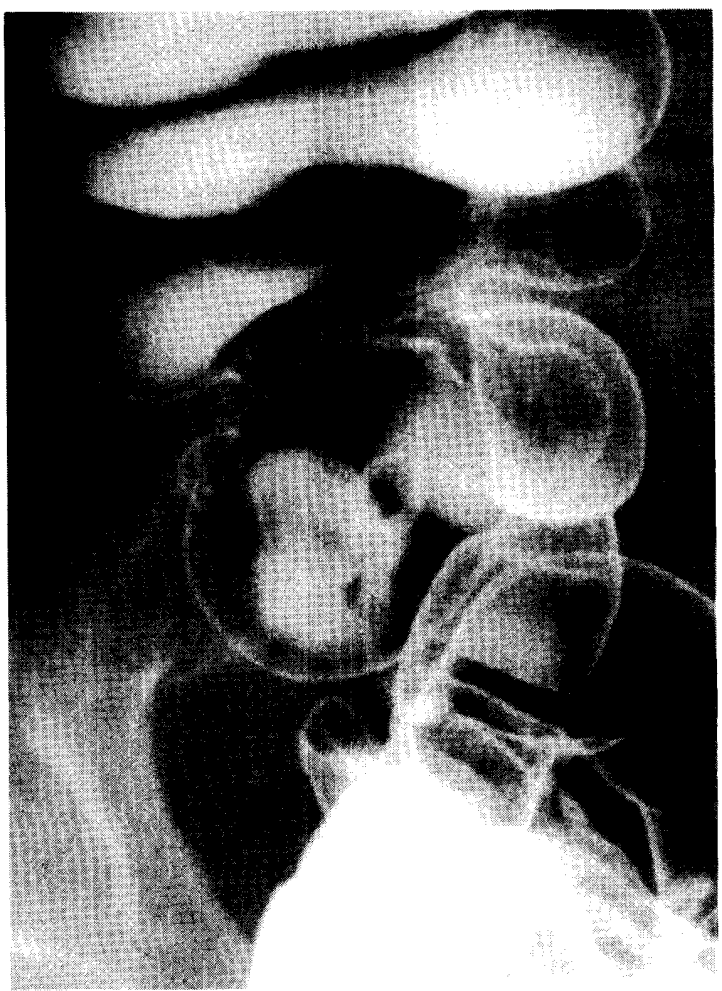

Fig. 5 Barium enema study shows carcinoma in the cecum with annular stenosis referred to as an apple-core lesion.

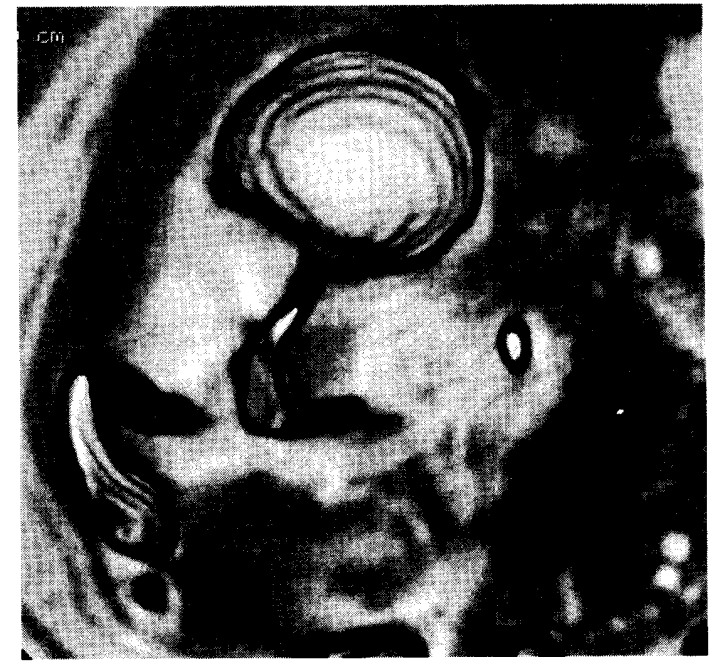

Fig. 6 A 3D-MPR-CT image, constructed with both 3D and MPR images, shows extracolonic invasion of the retroperitoneum. This method makes it possible to observe both intraluminal and extraluminal findings at the same time. 
像を作成することがMPRであるが，このMPRと3D-CT 画像の合成表示を行ったものが3D-MPR-CTである4! Fig.6に回盲部腫陽の3D-MPR-CTを示す。この像は axial像に近い面を表示したoblique面の3D-MPR-CTで あるが大腸管腔内の様子とともに癌の浸潤の状態を知 ることができる。このほか, coronal面, sagittal面な ど,さまざまな面の漫潤の程度が管腔内壁と同時に知 ることができ，手術範囲の決定に役立つ。

\section{3. 考 愳}

3D-CT-colonographyにおうてコンピュー夕支援の恩 恵を受けるのは，Fig.2に示した次元CT面で指定し た任意の位置でのリアルタイムVE表示である。内視 鏡検査では確認できない狭窄部より樑部や，検査上内 視鏡挿入困難な被検者, 内視鏡検査を拒否する被検者 に特に有効である。またこのVEの観察では管腔挿 入支援システムによって半自動的に視点の大腸への挿 入が可能である。これは管腔内表示画像の中で最も暗 い点を探しその方向に向かって自動進行させていくと いうものである。ただし，管腔内表示㣙像上に複数の 暗い点が存在する場合は，それらの平均点が進行方向 となる. 進行距離は数值入力により設定が可能であ る。例えば肛門部からVEによる挿入を始め回盲部ま で進行する場合，マウスのクリックのみである程度自 動的に管腔内を進むことができる。ただし，S状結腸 や，脾彎曲，肝彎曲のような急な進路の変更は Fig. 2a c のMPR表示画面に打いて，手動操作で axial, coronal, sagittal面に扮ける視野の指定を行う 必要がある場合がある。この方法によって良来長時間 費やして行っていた大腸全体の視点の移動が容易とな った。通常のVEではhaustraと呼ばれるヒダによって 死角が生じ病変を見落とすという欠点がある。これは 内視鏡検査においても生じる久点であるが，VEでは 内視鏡検査ではできない有効な解決方法が考えられ る.これはFig.2eに示したturn roundの手法である。こ れはある視点に扮ける視野を 180 反転し表示する方 法，すなわち振り返り観察である。肞門部から回盲部 まで進めた視点の軌跡を視野を 180 反転させながら回 盲部から肚門部まで戻ってくる万法をとることによ り， 口側から肚門側入進行する内視鏡画像が得られ る。この手法を利用することにより，視点の軌跡を再 度計算することなく通常の内視鏡では得られない肘門 方向への連続した画像が得られる.

マンモグラフィや胸部X線画像等のCADによる第一. の目的はスクリーニングで病変の見落としを減少させ ることである、VEによる管腔内病変の検索もスクリ 一ニングの一つとして研究を進める必要があるが，糞 便や残渣との鑑別がつきにくい欠点を有し, false positiveの増加が懸念される。その久点をさけるため 私見としてスクリーニング法に最も有望視しているの は3D-MPR-CTである.これはFig.6に示すような管腔 面に対して垂直な面のMPR像の表示とともに管腔内 はVEを表示するお法である。この手法を用いること により糞便や残渣との鑑別を䧻易にし，また，病变が 検出导机た場合，病変の浸潤の度合いも同時に知るこ とができる。現在の課題は，大腸管腔に垂直な面の 3D-MPR-CTの表示方法のもと肚門側から口側への往 復ナビゲーションの開発である。次世代の大腸のCAD の開発目標は，管腔から突出する隆起成分を二次元 CT面で抽出し，それを3D-MPR-CT上に表示し観察者 に読影上の注意を喚起することである。ただし，隆起 成分の中に空気を会有しているものや，水様性残渣に よって水平面を形成しているものは便として排除する 必要がある。

air image法およびDCCTは管腔外から観察する手法 であるが，従来の注腸撮影で必要とされていた多方向 撮影が1回の撮影でディジタルデータの保存により異 なる視野，異なる条件で画像が構築できる。ただし， この方法では注腸同様に腸と腸との重なりを生ずるた めに，精密検査としての適用はあるが，スクリーニン グ検査には適していない。

米国では10mm以トのポリープ(腺腫)が浸潤癌にな るのに10年かかると考えられているため，直徍 $10 \mathrm{~mm}$ 程度のポリープを検出できれば良いとされており，こ の3D-CT-colonographyで対応できると考えている．撮 影条件は被曝低減を重視し，あまり薄いスライス幅を 採用せず $5 \mathrm{~mm}$ 幅とした，当院では直径4－5mmの隆起 性病変なら検出できる結果を得ているため6 , 今後, 大腸の検相法の一つとして確立されていくであろうと 考える.

\section{4. 結 語}

コンピュータ支援による3D-CT-colonographyは，空 気を管腔内の造影剤とした低侵襲の大腸検査を可能と した。仮想内視鏡近似画像 (VE法)や，管腔内の空気 像を示しバリウム充満像に近似させた方法 (air image 法)，X線二重造影像に近似させた方法など，しきい 值や透明度の設定により，1回のスキャンによりさま ざまな表示が可能である。また，これらの表示方法に 加え，消化管管腔内表示とともに任意消化管断面の CT画像を表示する3D-CT画像とMPRの合成表示も可 能である。しかし, 現在の手法では視点を半自動的に 大腸管腔内部をナビゲートするのみであり，視野に病 変像が入ってきてもコンピュータは病変として認識せ ずそのまま通過してしまう。放射線画像の解析抢よび 定量化を自動的に行い病変を検出するという本格的な 
CADを適用するには, axial像またはMPR像の二次元 CT面での解析が必要であると考える. 現在のVE, 3D-MPR-CT法による病変検索では読影に多大な時間 を要するため，病変検出支援まで含めたCADの開発 を進める必要がある。
諆 辞

本研究を進めるにあたり，技術的援助をいただい た，GE横河メディカルシステムの方々に御礼申し上 げます。また，ヘリカルスキャンデータの利用に対し ご協力いただいた，当院内科丸山雅一氏，放射線部 立川智弘氏，根岸礼子氏に感謝します。

\section{参考文献}

1) Ogura $T$, Koizumi K, Kai S, et al.: Three-dimensional CT colonoscopy, comparison with colonoscopy and barium enema examination. Radiology, 197, 444, (1995).

2) 小倉敏裕, 小泉浩一, 甲斐俊吉, 他：ヘリカルスキャンCT を利用した直腸癌の三次元表示.日本消化器内視鏡学会雑 誌, 37, 1148-1156, (1995).

3) Ogura T, Koizumi K, and Maruyama M: 3D-CT colonoscopy of colorectal carcinoma. Proc of International Conference on Virtual Systems and Multimedia, 338-343, (1995).

4) 小倉敏裕, 丸山雅一：三次元CTとMPRの合成による胃腫 瘍の画像表示. Medical Imaging Technology, 16, 125130, (1988).

5) 小倉敏裕, 小泉浩一, 丸山雅一, 他：CTによる消化器癌の 診断一現状と将来への期待一。画像診断，17，11651173 , (1997).

6）小倉敏裕，小泉浩一，酒井達也，他：消化管病変の三次元 画像診断一現状と展望へリカルスキャンCTによる大腸三 次元構築一。胃と腸，33，187-196，（1998）.
7) 小倉敏裕：消化管3D-CT. 医用画像情報学会雑誌, 16 (3), 147-158, (1999).

8) Vining DJ: 3-D spiral CT of bowel yields virtual colonoscopy. Diagnostic Imag, 13-15, (1994).

9) Hara AK, Johnson CD, Reed JE, et al.: Colorectal polyp detection using computed tomographic colonography: two-versus threedimensional techniques. Radiology, 200, 49-54, (1996).

10）土井邦雄, 桂川茂彦, Giger ML：ディジタルラジオグラフ イにおけるコンピュータ支援診断の可能性. 日放技学誌, $45(5), 653-663,(1989)$.

11）林 宏光, 高木 亮, 市川太郎, 他：らせん走査型CTの新 しい技術-Multidetector-row (多列検出器型) CTを理解する ために一，日獨医報，44(2)，84-95，(1999).

12) 永井 純, 安達秀雄: 三次元CT血管造影法一血管疾患の新 しい診断法一. pp.3-77, メディカルサイエンスインターナ ショナル，東京，（1994）。

\section{図表の説明}

Fig. 1 空気を充満させることによって作成した下行結腸の仮想内視鏡像.

Fig. 2 大腸の仮想内視鏡ナビゲートプログラム．MPR画像上で視野を決定することによりさまざまな視野の仮想内視鏡画像がリ アルタイムに得られる $(\mathbf{a} \sim \mathrm{c})$. 内視鏡では不可能であるが，仮想内視鏡は狭窄部を越えることができる．このイメージは 狭窄の反対側から癌病変を観察したものである $(\mathrm{d})$. 横行結腸において視野を反転させて表示した仮想内視鏡画像 $(\mathrm{e})$.

Fig. 3 バリウム充満像に近似表示したエアーイメージ法.

Fig. 4 注腸近似表示を行ったDCCT法による画像.

Fig. 5 アップルコアといわれる輪状狭窄を有する回盲部の大腸癌を示す注腸像.

Fig. 6 三次元画像とMPRを合成表示した3D-MPR-CT画像.この画像では腹膜の浸潤を示す。本法は管腔内腔への浸潤と外側への 浸潤を同時に観察が可能である. 